[97] $\beta$-置換アクリルアミドの水素移動重合による $\alpha$-ポリペプチドの合成 (1968 年 6 月 1 日受理)

\title{
今西幸男 ${ }^{*}$. 安藤忠勝* . 岡村誠三*
}

\begin{abstract}
要 旨 $\beta$-炭素に電子吸引性の置換基を持ったアクリルアミド誘導体の水素移動重合により， $\alpha$-ポリ ペプチドを合成することを試み, トランスーpーニトロ桂皮酸アミドとトランスー $\beta$-クロルアクリルアミ ドを合成し，塩基性触媒による重合を行なった。トランスー $p$-ニトロ桂皮酸アミドは $\eta_{s p} / C \fallingdotseq 0.09$ のポ リマーを与え, ポリマー構成単位の約 $1 / 3$ はペプチド結合を有し, その中には $\alpha$-ペプチド結合が存在 することが確かめられた。一方，トランスー桂皮酸アミドはポリペプチドは与えるが， $\alpha$-ペプチド結台 を生じない。 $\alpha$-ペプチド結合を生じるためには電子吸引性の強いニトロ基が必要であるとわかった。 トランスー $\beta$ クロルアクリルアミドは $\eta_{s p} / C \fallingdotseq 0.1$ のポリマーを与充た。ポリマー構成単位の約 $1 / 4$ は ベプチド結合を有するが， $\alpha$-ペプチド結合が存在するかどらかは現在のところ不明である。
\end{abstract}

\section{1. 緒言}

1957 年に Breslow ら"は塩基性触媒によるアクリル アミドの重合でポリー $\beta$ アラニンが生成することを発見 した。その反応機構は多くの研究者らの議論の対象とな り，現在までのところ，確定的とは言光ないが，一応， 次のように考えるのが妥当であるとされている。<smiles>[R]C[C@H](C=[R]C)C(N)=O</smiles><smiles>[R]CC(C)[18OH]</smiles><smiles>C#CCCC(=O)NO</smiles>

すなわち，それまで予想されていたような、ビニル基の 開裂のみによって生ずるポリアクリルアミドは得られ ず, アミド基の水素移動を伴ってポリマー主鎖中にペプ チド結合を有するポリペプチドが得られた。類似の反応 が多くのアクリルアミド誘導体について, 種々の条件下 で検討されてきたか，すべての場合，得られたポリマー は二つのペプチド基の間に 2 個の炭素原子をはさむ $\beta$ ポリペブチドであった。

最近 Bamford および著者の一人 2) $\beta$-置換アクリ ルアミドの塩基性触媒による重合に扣いて, 次の機構で $\alpha$-ポリペブチド（2 個のペプチド基の間に 1 個の炭素原 子をはさむ）が生成する可能性を報告した。<smiles>[R]C(C#CC([X])C([R])C)C(N)=O</smiles>

* 京都大学工学部高分子化学教室（京都市左京区吉田 本町)<smiles></smiles>

すなわち, アクリルアミドの $\beta$-水素を電子吸引性の大 きい置換基 (X) で置換することにより, 攻撃アニオン の付加をアミド基がついた炭素の上で行なわせるといら ことが, 従来の方法と異なった点である。

タンパク質のモデル化合物としての $\alpha$-ポリペプチド の合成は重要な意義を有し, 近年, 広く行なわれている ことであるが，そのすべては出発物質として $\alpha$-アミ， 酸を使用している。したがって，もし上記の方法で合成 の簡単なビニルモノマー(アクリルアミド誘導体)から種 々の置換基 $\left(\mathrm{CH}_{2} \mathrm{X}\right)$ を持った $\alpha$-ポリペプチドを合成する ことが可能であれば非常に有用である。そこで, 本研究に

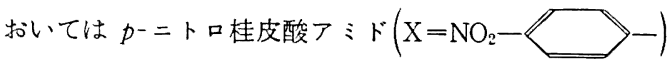
および $\beta$ クロルアクリルアミド $(\mathrm{X}=\mathrm{Cl}-)$ の 2 種のア クリルアミド誘導体を合成し，それらの塩基性触媒によ る重合反応性を種々の条件下で検討した。そして生成ポ リマーの性質を, 特に $\alpha$-ペプチド結合が生成している かどらかを中心にして研究した。

なお，最近，岩倉ら゙が桂皮酸アミト $(\mathrm{X}=\longrightarrow$ の塩基性触媒による重合で $\beta$ ホポリペプチドを得たと報 告しているので, このものについても比較検討を加え た。

\section{2. 実 験}

2.1 試 薬 


\subsection{1 モノマー}

p-ニトロ桂皮酸アミド (VI) は桂皮酸エチル（I）か ら以下の方法で合成した。<smiles>CCOC(=O)C=CC1CCCCC1C=CC(=O)OCC</smiles><smiles>CCOC(=O)C=C1CCC2(C)CCC(C1)C2[N+](=O)[O-]</smiles><smiles>O=C(O)C=Cc1ccc([N+](=O)[O-])cc1</smiles>

(IV)

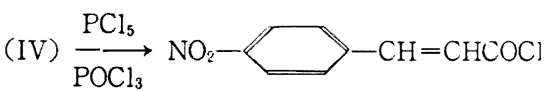

( $\mathrm{V}$ )<smiles>CC(N)(Cl)N(N)Oc1ccc(C=CC(N)=O)cc1</smiles>

(VI)

(trans)

(I) $\rightarrow$ (III) の反応は Guastalla4! の方法に準して行な った。(III)は3 回エタノールから再結晶して精製した。 收率 $15.7 \%$, 融点 $136 \sim 137^{\circ} \mathrm{C}$ (文献値 $135^{\circ} \mathrm{C}$ )。元素 分析値は

$\begin{array}{llll} & \mathrm{C} \% & \mathrm{H} \% & \mathrm{~N} \% \\ \text { 理諭值 } & 59.73 & 5.00 & 6.33 \\ \text { 実測値 } & 59.91 & 4.80 & 6.66\end{array}$

（III）を $5 \mathrm{~g}$ とり,等モルの無水炭酸ソーダの 1 規定水 溶液と混ぜ，4時間還流した。不溶部分を口別した口液 を塩酸で中和して粗 $p$-ニト口桂皮酸を得た。水洗乾燥 後エタノールから再結晶により (IV) を得た。収率 73.2 $\%$, 融点 $275^{\circ} \mathrm{C}$ (文献值 $276^{\circ} \mathrm{C}$ )。

$(\mathrm{IV}) \rightarrow(\mathrm{V})$ の反応は $0^{-}$二トロ桂皮酸クロライドの合 成に関する Fischer ら の゙ の方法に準してて行なった。 $5 \mathrm{~g}$ の (IV) を $100 \mathrm{ml}$ の $\mathrm{POCl}_{3}$ に溶かし, $10.8 \mathrm{~g}$ の $\mathrm{PCl}_{5}$ を加えて還流した。 $\mathrm{POCl}_{3}$ を除去して得られる固体を $\mathrm{CHCl}_{3}$ から 3 回再結晶して精製した。融点 $142^{\circ} \mathrm{C}$ (文献 值 $125^{\circ} \mathrm{C}$ )。

(V)を $\mathrm{CHCl}_{3}$ に溶かし, $10^{\circ} \mathrm{C}$ 以下の温度で $\mathrm{NH}_{3}$ ガ スを通して得られた白色沈殿から $\mathrm{NH}_{4} \mathrm{Cl}$ を除いて得た 固体を、3回エタノールから再結晶し(VI) を得た。黄 色の針状結晶で, (IV) からの収率 $44.5 \%$, 融点 $222^{\circ} \mathrm{C}$ でった。元素分析値は

$\begin{array}{llll} & \mathrm{C} \% & \mathrm{H} \% & \mathrm{~N} \% \\ \text { 理諭値 } & 56.25 & 4.17 & 14.58\end{array}$

\section{実測值 $56.24 \quad 4.25 \quad 14.59$}

ß-クロルアクリルアミド (XI) はプロパルギルアルコ ール（VII）から以下の方法で合成した。

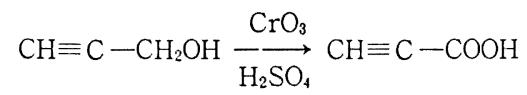

(VII)

(VIII)

$$
\text { (VIII) } \stackrel{\mathrm{HCl}}{\longrightarrow} \mathrm{CHCl}=\mathrm{CH}-\mathrm{COOH}
$$

(IX)

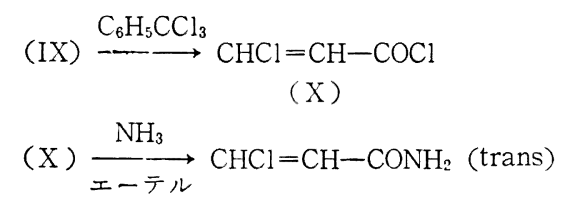

(XI)

$(\mathrm{VII}) \rightarrow(\mathrm{VIII})$ の反応はWolf(6) の方法に従って行なっ た。(VIII) を減圧蒸留によって精製した。沸点 $57^{\circ} \mathrm{C} / 12$ $\mathrm{mmHg}$ (文献値 $52.4 \sim 54.0^{\circ} \mathrm{C} / 9 \mathrm{mmHg}$ )。収率 $57.7 \%$

(VIII) $\rightarrow$ (IX) の反応は Backer ら" の方法に従っ て行なった。(IX) の沸点 $88.5^{\circ} \mathrm{C} / 17 \mathrm{mmHg}$ (文献値 $94^{\circ} \mathrm{C} / 18 \mathrm{mmHg}$ )。収率 $14.5 \%$ 。

$(\mathrm{IX}) \rightarrow(\mathrm{X})$ の反応は Gryszkiewicz-Trochimowski ら ${ }^{81}$ の方法汇従って行なった。(IX)はメタノールから 3 回再絬晶して精彆した。（XI）は白色板状結晶で融点 $151.0 \sim 152.5^{\circ} \mathrm{C}$ (文献值 $143.5 \sim 145^{\circ} \mathrm{C}$ )。收率 $61.5 \%$ 。 元素分析値は

$\begin{array}{cccc} & \mathrm{C} \% & \mathrm{H} \% & \mathrm{~N} \% \\ \text { 理論值 } & 34.15 & 3.82 & 13.27 \\ \text { 実測值 } & 34.95 & 3.90 & 13.47\end{array}$

桂皮酸アミドは市肘の桂皮酸クロライド（東京化成社 製) から Marvel ら91 の方法に従って合成しベンゼ ンから 3 回再結晶して精製した。

\section{1 .2 触 媒}

$n$-プチルリチウムは市肘の $n$-ヘキサン溶液（濃 度 4 $\mathrm{mol} / l$ ) を使用した。

n-ブチルマグネシウムブロマイド（グリニ+ー試薬） はエーテル中で奥化 nーブチルとマグネシウムとから合 成した。湶度を, 水と反応して生しる $\mathrm{MgBr}(\mathrm{OH})$ に過 剩の $\mathrm{HCl}$ を加え $\mathrm{NaOH}$ で这滴定で決定したところ 1.0 $\mathrm{mol} / \mathrm{l}$ であった。

ナトリゥム三級ブトキシドは, 特級の三級ブタノール を金属ナトリウムから蒸留して脱水し, これに金属ナト リウムを加之（アルコール大過剩）ゆっくりと加熱，罡 流して合成した。余分のアルコールを減圧蒸留によって 除去精製した。

\subsection{3 溶 媒}

ジメチルホルムアミド（DMF）は市肘特級品を $\mathrm{BaO}$ で脱水後，2回減圧蒸留して精製した。沸点 $37^{\circ} \mathrm{C} / 8$ 
$\mathrm{mmHg}$

ジオキサン（DO）は市販特級品を金属ナトリウムとと もに 1 昼夜還流後, 減圧蒸留によって精製した。

ジメチルスルホキシド（DMSO）は常圧で少量の無水 ベンゼンを加光，共沸させて脱水後， $\mathrm{BaO}$ を加えて加熱 後減圧蒸留して精製した。沸点 $63.0^{\circ} \mathrm{C} / 7.5 \mathrm{mmHg}$ 。

クロルベンゼン (CB) は市販特級試薬を希 $\mathrm{K}_{2} \mathrm{CO}_{3}$ 水 溶液で, 洗浄後 $\mathrm{P}_{2} \mathrm{O}_{5}$ 上で 1 昼夜脱水し, 減圧蒸留によ り精製した。沸点 $44.2^{\circ} \mathrm{C} / 38 \mathrm{mmHg}$ 。

\section{2 重合操作}

\subsection{1 $p$-ニトロ桂皮酸アミドの重合}

所定量のモノマーと溶媒を 3 角フラスコに入れ，オイ ルバスで所定の温度に加熱溶解後, 窒素気流中で触媒を 加えて重合を行なった。所定時間後, 反応液を室温のエ ーテルに注ぎ，反応生成物を沈殿させて重合を停止し た。沈殿を口別し, エーテルで洗浄後, 乾燥した。この ものから末反応モノマーを除くため, ソックスレー抽出 器を用いてェタノール，あるいはベンゼンによる抽出を 行なった。重量法によって収率を計算した。

\section{2 .2 桂皮酸了ミドの重合}

上記と同じ操作で重合し，反応生成物からの未反応モ ノマーの抽出はペンゼンで行なった。

\section{$2.2 .3 \beta$-クロルアクリルアミドの重合}

上記と同じ操作で重合した。反応生成物が水アメ状の ため, ソックスレー抽出器による抽出は行なわず，エー テルでくり这し洗浄後減王乾燥した。

\section{3 赤外スペクトル}

測定装置は島津自記赤外分光光度計 IR-27 型を用い, $\mathrm{KBr}$ 錠剤法で測定した。

\section{4 窒素の定量}

第一アミドの定量101はケールダールフラスコに試料約 $3 \mathrm{mg}$ を精科し， $40 \% \mathrm{NaOH}$ 水溶液約 $8 \mathrm{cc}$ を加光, 20 分
間水蒸気蒸留して発生する $\mathrm{NH}_{3}$ を $2 \%$ ホウ酸水溶液に 取り出し，メチルレッドとブロムクレゾールグリーンの 混合指示薬を用い, $\mathrm{HCl}$ 規定液で滴定して行なった。

全窒素の定量 ${ }^{11}$ は， $\mathrm{NO}_{2}$ 基を持つものについてはそ れを $\mathrm{NH}_{2}$ に還元後，試料を濃硫酸と加熱して全窒素を 硫酸アンモニウムに変えたのち, アルカリの添加により $\mathrm{NH}_{3}$ として取り出し, 上記のごとく滴定して行なった。 なお，定量にはミクロケルダール分析装置を用いた。

\section{5 反応生成物の加水分解之その分析}

反応生成物の加水分解は $10 \mathrm{~N}-\mathrm{HCl}$ 水溶液中 $10 \mathrm{mg} / \mathrm{cc}$ の濃度で行なった。試料をガラス管内に封入し， $110^{\circ} \mathrm{C}$ で 24 時間加熱して行なった。東洋沪紙 No. 51 を用い て加水分解物のペーパークロマトグラフィーを行ない, ニンヒドリン反応による発色からアミノ酸の同定を行な った。展開液としてはフェノールー水 $(4: 1$ 体積比) (P-Wと略記) および $n$-ブタノール-酶酸-水 $(18: 2: 5$ 体積比）(B-A-W と略記）の 2 種を用いた。

\section{6 粘 度}

オストワルド粘度計を用いシシクロル酶酸を溶媒とし て, $30^{\circ} \mathrm{C}$ で $\eta_{s p} / C$ を測定した。

\section{3. 結果と考察}

\section{$3.1 p$-ニトロ桂皮酸アミドの重合}

$p$-ニトロ桂皮酸フミドの種々の条件下での重合と反 応生成物の収量との関係を Table 1 亿示した。反応生 成物の大部分はェタノールに溶解し, 未反応モノマーの 抽出にはベンビンの方が適当であった。ただしモノマー のベンゼン中への溶解度はかなり低いので, 長時間抽出 する必要があり，本実験では $3 〜 5$ 昼夜抽出を行なった。 モノマーの DO 中への溶解度が低い上に, DO の沸点 が重合温度に近いため操作上困難があった。DO 中での 反応生成物中に多量の未反応モノマーが含まれているこ

Table 1. Polymerization of $p$-nitrocinnamide.

$\mathrm{M}_{]_{0}}: 0.52 \mathrm{~mol} / \mathrm{l}(1 \mathrm{~g} / 10 \mathrm{ml})$, Polymerization time $24 \mathrm{hr}$, Polymerization temperature $90^{\circ} \mathrm{C}$

\begin{tabular}{|c|c|c|c|c|c|c|c|}
\hline \multirow[b]{2}{*}{ No. } & \multicolumn{2}{|c|}{ Catalyst } & \multirow[b]{2}{*}{ Solvent } & \multicolumn{4}{|c|}{ Procuct } \\
\hline & Kind & $\begin{array}{c}\text { Concentration } \\
(\mathrm{m} \mathrm{mol} / \mathrm{l})\end{array}$ & & $\begin{array}{c}\text { Extract } \\
(\mathrm{g})\end{array}$ & $\begin{array}{l}\text { Residue } \\
(\mathrm{g})\end{array}$ & $\begin{array}{l}\text { Yield } \\
(\%)\end{array}$ & $\eta_{s p} / C$ \\
\hline 1 & $n-\mathrm{C}_{4} \mathrm{H}_{9} \mathrm{Li}$ & 80 & $\mathrm{DMF}$ & $0.588^{a}$ & a little & & \\
\hline 2 & $t-\mathrm{C}_{4} \mathrm{H}_{9} \mathrm{ONa}$ & 104 & $\mathrm{DMF}$ & $0.884^{a)}$ & trace & & \\
\hline 3 & $n-\mathrm{C}_{4} \mathrm{H}_{9} \mathrm{Li}$ & 80 & $\mathrm{DO}$ & $0.771^{13}$ & a little & & \\
\hline 4 & $t-\mathrm{C}_{4} \mathrm{H}_{9} \mathrm{ONa}$ & 104 & $\mathrm{DO}$ & $0.983^{a)}$ & trace & & \\
\hline 5 & $n-\mathrm{C}_{4} \mathrm{H}_{9} \mathrm{Li}$ & 80 & $\mathrm{DMF}$ & $\square^{\mathrm{c}}$ & $0.432^{\mathrm{bl}}$ & 43.2 & $0.093(C=1.00 \mathrm{~g} / \mathrm{d} l)$ \\
\hline 6 & $n-\mathrm{C}_{4} \mathrm{H}_{9} \mathrm{MgBr}$ & 100 & $\mathrm{DMF}$ & $\longrightarrow^{c}$ & $0.465^{\text {b }}$ & 46.5 & $0.097(C=1.03 \mathrm{~g} / \mathrm{d} l)$ \\
\hline
\end{tabular}

a) Extracted by ethanol.

b) Residue when extracted by benzene.

c) No reaction product was extracted by benzene. 
とが赤外スペクトルによって示された。これらのことか ら, 重合溶媒としては DO よりも DMF の方が適当であ ることがわかった。

使用した 3 種の触媒のうち $t-\mathrm{C}_{4} \mathrm{H}_{9} \mathrm{ONa}$ のみは大量に 用いると溶媒に溶けず, 反応生成物中に混在してくる。

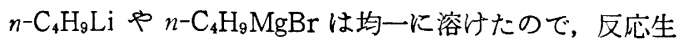
成物収量に対する影響を比較したが，差は注とんど認め られなかった。

次に反応生成物がどのよらな構造をとっているかとい うことに関して若干の検討を加えた。 $\beta$-置換基をXで表 ふした $\beta$-置換フクリルアミドの塩基性触媒による重合 ては,ポリマーが生成するならば,ポリマーは次の 3 種類 の反復単位の組み合わせから成っていると推定される。 $\begin{array}{cc}\sim(\mathrm{CH}-\mathrm{CONH})_{x}- & \left(\mathrm{CH}-\mathrm{CH}_{2}-\mathrm{CONH}\right)_{v}- \\ \mid & \mid \\ \mathrm{CH}_{2} & \mathrm{X} \\ \mid & \\ \mathrm{X} & \end{array}$
(A)<smiles>[X]C(C)C(CC)C(N)=O</smiles>

(C)

反復単位 $(\mathrm{A})$ は $\alpha$-ペプチド結合を持つ単位であり, 攻 䌘アニオンの付加がモノマーのアミド基を持った炭素の 上に起こり,引き続いてアミド水素の移動が起こること によって生しる。反復単位 (B)は $\beta$-ペプチド結合を持 つ単位であり, 攻擎了ニオンの付加がモノマーの置換基 Xを持った炭素の上に起こり, 引き続いてアミド皮素の 移動が起こることによって生じる。反復単位 (C) は炭 素-炭素 2 重結合の開裂のみが起こり, アミド水素の移 動を伴わない場合に生じる。このよらないわゆるビニル 重合が水素移動重合に混しって起こることはアクリルア ミドなどについて明らかにされている ${ }^{12 i} 。$

ところで，ポリマー中に反復単位 (A) を導入するこ とと, その割合を定量することが本研究の目的であっ た。まず，モノマーと代表的な反応生成物の赤外スペク トルをFig. 1に示した。モノマー（Fig. 1-a）に执いて 存在した trans 2 重結合に基く $970 \mathrm{~cm}^{-1}$ の吸収が反応 生成物（Fig. 1-b）に打いてはほとんど羿められない。 また, 反応生成物中には $1500 \sim 1600 \mathrm{~cm}^{-1}$ に置換アミド 結合に基くと思われるブロードな吸収が現われた。これ らの事実は, アクリルアミドの重合の場合との類似13: か ら，ポリマー（ポリペプチド）が得られたことを示すも のと解釉される。ポリマーの生成は, 反応生成物 No. 5 ๑) $\eta_{s p} / C$ か $0.093(C=1.00 \mathrm{~g} / \mathrm{d} l)$ であり, 同じく No. 6 の $\eta_{s p} / C$ が $0.097(C=1.03 \mathrm{~g} / \mathrm{d} l)$ であることからも 支持される。

次に反応生成物がポリペプチドであるかどうかを明ら

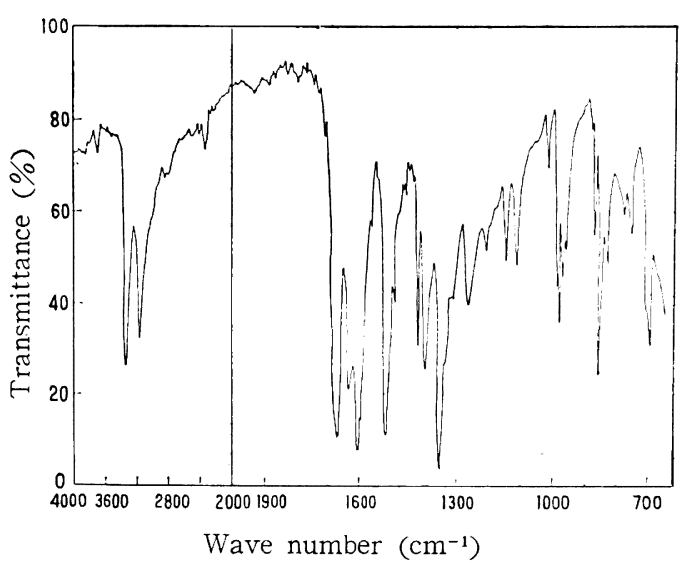

Fig. 1-a. Infrared spectrum of trans-p-nitrocinnamide

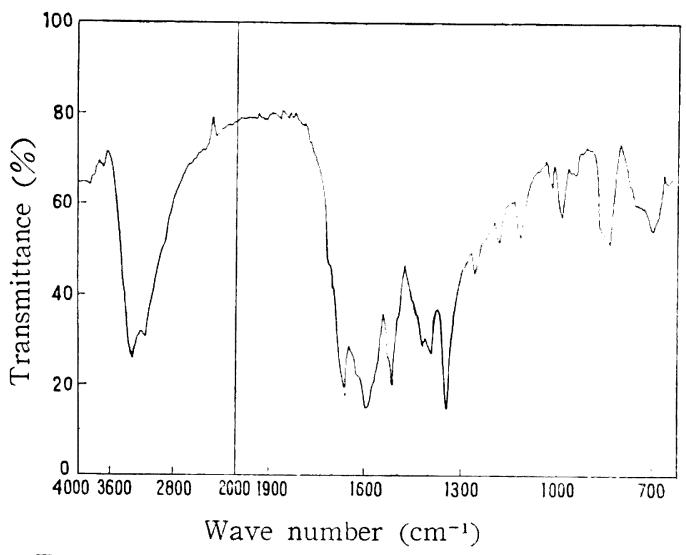

Fig. 1-b. Infrared spectrum of poly-trans-p. nitrocinnamide.

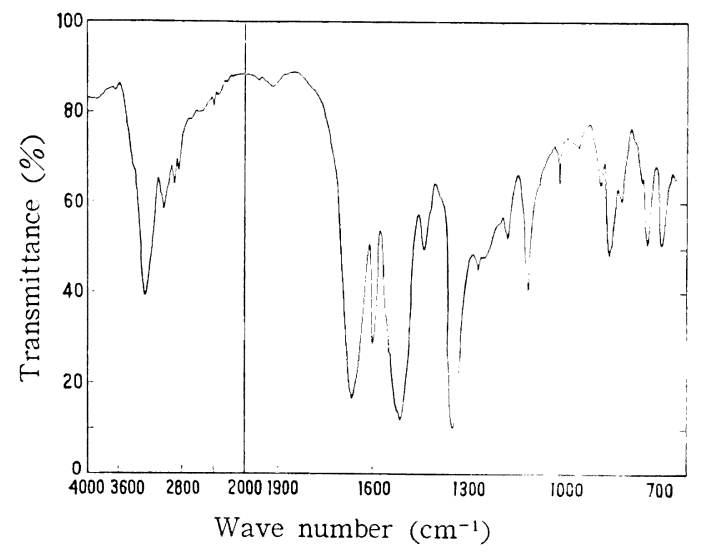

Fig. 1-c. Infrared spectrum of poly-p-nitrophenylalanine. 
Table 2. $R_{f}$ values of the hydrolyzates of poly-p-nitrocinnamide.

\begin{tabular}{|c|c|c|c|c|c|c|c|c|c|}
\hline & Sample & & $\mathrm{P}-\mathrm{W}$ & & & & B-A-W & & \\
\hline & Ethanol insoluble part & $\begin{array}{l}0.70(\mathrm{~m}) \\
0.77(\mathrm{w})\end{array}$ & & $\begin{array}{l}0.26(w) \\
0.29(w)\end{array}$ & & & $\begin{array}{l}0.27(\mathrm{w}) \\
0.28(\mathrm{w})\end{array}$ & 0.19 (w) & \\
\hline 1 & Ethanol soluble part & $0.78(\mathrm{~s})$ & & $0.16(\mathrm{~m})$ & & $\begin{array}{l}0.54(\mathrm{~m}) \\
0.53(\mathrm{~s})\end{array}$ & $0.24(\mathrm{~m})$ & $\begin{array}{l}0.19(\mathrm{~m}) \\
0.15(\mathrm{~m})\end{array}$ & \\
\hline No. 2 & Ethanol soluble part & $0.82(w)$ & & & & $\begin{array}{l}0.57(\mathrm{w}) \\
0.52(\mathrm{w})\end{array}$ & $0.29(\mathrm{w})$ & $\begin{array}{l}0.18(w) \\
0.18(w)\end{array}$ & \\
\hline No 3 & Ethanol insoluble part & $0.84(\mathrm{~s})$ & & $0.26(\mathrm{~m})$ & & $0.40(w)$ & & $\begin{array}{l}0.17(w) \\
0.17(w)\end{array}$ & $\begin{array}{l}0.13(w) \\
0.13(w)\end{array}$ \\
\hline & Ethanol soluble part & $0.64(\mathrm{~m})$ & & & & $\begin{array}{l}0.44(\mathrm{w}) \\
0.53(\mathrm{~m})\end{array}$ & $0.28(w)$ & $\begin{array}{l}0.18(\mathrm{w}) \\
0.18(\mathrm{~m})\end{array}$ & \\
\hline No. 4 & Ethanol soluble part & & & $0.26(\mathrm{~m})$ & & & & $\begin{array}{l}0.19(\mathrm{~m}) \\
0.19(\mathrm{~m})\end{array}$ & \\
\hline No. 5 & Benzene insoluble part & $\begin{array}{l}0.73(\mathrm{~s}) \\
0.75(\mathrm{~s})\end{array}$ & $\begin{array}{l}0.53(w) \\
0.62(w)\end{array}$ & $\begin{array}{l}0.25(\mathrm{~m}) \\
0.24(\mathrm{~m})\end{array}$ & & $\begin{array}{l}0.53(\mathrm{w}) \\
0.52(\mathrm{~s})\end{array}$ & $\begin{array}{l}0.27(\mathrm{~m}) \\
0.28(\mathrm{w})\end{array}$ & $\begin{array}{l}0.17(\mathrm{~s}) \\
0.16(\mathrm{~m})^{*}\end{array}$ & \\
\hline No. 6 & Benzene insoluble part & $0.78(\mathrm{~s})$ & & $0.22(\mathrm{~m})$ & & $0.59(\mathrm{w})$ & $0.28(\mathrm{~m})$ & $0.22(\mathrm{~m})$ & \\
\hline Poly & -p-nitrophenylalanine* & $\begin{array}{l}0.77(\mathrm{~s}) \\
0.79(\mathrm{~s})\end{array}$ & & $\begin{array}{l}0.28(\mathrm{w}) \\
0.27(\mathrm{w})\end{array}$ & $\begin{array}{l}0.75(\mathrm{~s}) \\
0.78(\mathrm{~s})\end{array}$ & $\begin{array}{l}0.53(\mathrm{~s}) \\
0.55(\mathrm{~s})\end{array}$ & $0.30(w)$ & $\begin{array}{l}0.18(w) \\
0.20(w)\end{array}$ & $\begin{array}{l}0.12(\mathrm{w}) \\
0.12(\mathrm{w})\end{array}$ \\
\hline$p$-nit & rophenylalanine & $0.78(\mathrm{~s})$ & & & & $0.53(\mathrm{~s})$ & & & \\
\hline
\end{tabular}

* Obtained by the $n$-hexylamine-initiated polymerization of $p$-nitrophenylalanine NCA

** Hydrolyzed for $48 \mathrm{hr}$

かにするために, 反応生成物の加水分解を行なった。そ の結果, 加水分解物はニンヒドリンによる呈色反応を示 し、アミノ酸を含んでいること,すなわち反応生成物が ポリペプチドであったことが確かめられた。ところでも し水素移動を伴ら生長反応が 2 回以上連続して起こり, その中に反復単位 (A) が含まれていると加水分解物中 には そこで加水分解物のペーハーークロマトグラフィーを行な い, アミノ酸の $R_{f}$ 值を決定し, 標準物質として合成し た $p$-ニトロフェニルアラニンの $R_{f}$ 值との比較を行な った。実験結果を Table 2 に示した。

Table 2 の $R$, 值の比較加加水分解物中に $p^{-}=1$ ロフェニルアラニンが存在していることが明らかである。 すなわち展開液として B-A-Wを用いた場合， フェニルアラニン標染陚料は $R_{f}=0.53$ にただつつの ポットを与えた。さらにポリーpーニトロフェニルアラニ ン樌準試料の加水分解物も $R_{f}=0.53 \sim 0.55$ に強いスポ ットを与えた。一方, 本研究で得られた試料の加水分解 物はNo. 4 を除いて, $R_{f}=0.53$ 付近にスポットを与 えた。No. 6 のみ $R_{f}=0.59$ とやや大きい值を与えたが,
これは測定温度が他の試料と異なるためであろう。同時 に行なったポリーpーニトロフェニルアラニン加水分解物 も $R_{f}=0.59$ を与えた。展開液として $\mathrm{P}-\mathrm{W}$ を用いたと きにも，標準試料および本研究で得られた試料の加水分 解物（No. 4 を除く）ともに $R_{f}=0.8$ 付近に強いスポ ットを与光た。したがって本研究で得られたポリペプチ ドは $\alpha$-ペプチド結合 $(\mathrm{A})$ を含んでいたことが明らかと なった。

加水分解物が $p$-ニトロフェニルアラニン以外のアミ ノ酸をいく種類か含んでいたことは, Table 2 でたとえ ば B-A-W 法で $R_{f}=0.53$ 以外に多くのスポットを与え たことから明らかである。これは，一つには加水分解が 不完全であったこと, もら一つにはポリマーが反復単位 （B）や（C）を含んでいたためと考光られる。前者に 対する証拠としては, Table 2 の試料 No. 5 の加水分 解を 48 時間続行したところ, $R_{f}=0.52$ の $p$-ニトロ ェニルアラニンに基くスポットの強度が著しく增加し, 他の $R_{f}$ 值のスポットの強度が相対的に減少したことが 挙げられる。後者に対する証拠としては, 反応生成物の 赤外スペクトル Fig. 1-b が，ポリーp-ニトロフェニル 
Table 3. Nitrogen analysis of poly- $p$-nitrocinnamide No. 5 of Table 1.

\begin{tabular}{|c|c|c|}
\hline \multicolumn{2}{|c|}{ Total nitrogen $(\%)$} & \multirow{2}{*}{$\begin{array}{c}\text { Amide nitrogen } \\
(\%)\end{array}$} \\
\hline Theoretical & Observed & \\
\hline 14. $58^{*}$ & $11.85 \pm 0.24^{* *}$ & $4.03 \pm 1.07^{* * *}$ \\
\hline
\end{tabular}

* Value for monomer

** Mean value of the data in duplicate

*** Mean value of the data in six experiments

アラニンの赤外スペクトル Fig. 1-c と完全には同一で ないことが挙げられる。

反応生成物中にペプチド結合 $(\mathrm{A}+\mathrm{B})$ がどの程度含ま れているかについて検討した。もし, 反復単位 (C) が 存在するとアミド基が残るので, その窒素をぺプチド結 合の窒素と区別できるはずである。この目的のため試料 No. 5 の全窒素に対するアミド窒素の割合をケルダール 法によって求めた。結果を Table 3 に示した。ここで 反応生成物の全窒素量が理論值の約 $80 \%$ に減少してい るのは, 重合以外の副反応が起こっているためであろ ら。このことは, $p$-ニトロ桂皮酸アミドが黄色であり, ポリーp-ニトロフェニルアラニンが淡黄色であるにもか かわらず, 反応生成物が濃い褐色であることからも示唆 される。副反応がどのようなものであるかは確認されて いない。一方，アミド窒素の測定值にばらつきが大きい のは, 反応生成物がカセインーダ水溶液に溶けにくいこ とによるものであろう。上記の副反応を無視して, 全窒 素量に対するアミド窒素量の比が反復単位 (C) の割合 を示すものと考えると，比は 0.34 となるので，ポリマ 一中の反復単位の約 $2 / 3$ は構造 (C) をとっていると考 えられる。

反復単位 (B) もポリマー中に存在し, 加水分解の際, （B）から生じた $\beta$ アアミノ酸も加水分解物中に存在して いたと考えられるが， $p$-ニトロフェニルー - ーアラニン真 正サンプルが合成されなかったので，このことは確認さ
Table 4. Polymermerization of cinnamide $[\mathrm{M}]_{0}: 0.68 \mathrm{~mol} / \mathrm{l}(1 \mathrm{~g} / 10 \mathrm{ml})$ Polymerization time $24 \mathrm{hr}$ Polymerization temperature $90^{\circ} \mathrm{C}$ Solvent: DMF

\begin{tabular}{c|c|c|c|c}
\hline \hline \multirow{2}{*}{ No. } & \multicolumn{2}{|c|}{ Catalyst } & \multicolumn{2}{c}{ Product* } \\
\cline { 2 - 5 } \cline { 4 - 5 } & Kind & $\begin{array}{c}\text { Concentration } \\
(\mathrm{m} \mathrm{mol} / l)\end{array}$ & $\begin{array}{c}\text { Weight } \\
(\mathrm{g})\end{array}$ & $\begin{array}{c}\text { Yield } \\
(\%)\end{array}$ \\
\hline 7 & $n-\mathrm{C}_{4} \mathrm{H}_{9} \mathrm{Li}$ & 80 & 0.297 & 29.7 \\
8 & $t-\mathrm{C}_{4} \mathrm{H}_{9} \mathrm{ONa}$ & 104 & 0.146 & 14.6 \\
\hline
\end{tabular}

* Benzene insoluble part

れていない。

\section{2 桂皮酸アミドの重合}

すでに緒言でも述べたように，強い電子吸引性置鲃基 Xの作用により， $\alpha$-ポリペプチドを合成することが本研 究の目的であった。そこで置換基Xの電子吸引性の影证 について若干の知見を得るために，桂皮酸アミドの重合 を行なった。ニトロ基が存在しないと電子吸引性が弱く なって $\alpha$-ヘプチドの生成には不適当であると予想され る。重合と反応生成物の加水分解の実験結果を Table 4 と 5 に示した。

反応生成物がポリマーであることは赤外スペクトルの 比較から明らかである。すなわち，桂皮酸了ミドにおい て認められた $970 \mathrm{~cm}^{-1}$ の trans 2 重結合の吸収が, 反 応生成物に打いてはたいへん弱くなっている。一方, 反 応生成物には 1500 $1600 \mathrm{~cm}^{-1}$ に置換アミド基に基く吸 収が現われた。

反応生成物中に $\alpha$-ペプチド結合 (A) が存在するなら ば，加水分解物中にはフェニルアラニンが存在するはず である。しかし， Table 5 において展開液に B-A-W を用いたときの $R_{f}$ 值から，加水分解物中にはフェニル アラニンは存在していないといえる。この結諭は岩倉ら の得た結論と一致する。したがってアクリルアミド誘導

Table 5. $R_{f}$ values of the hydrolyzates of poly-cinnamide.

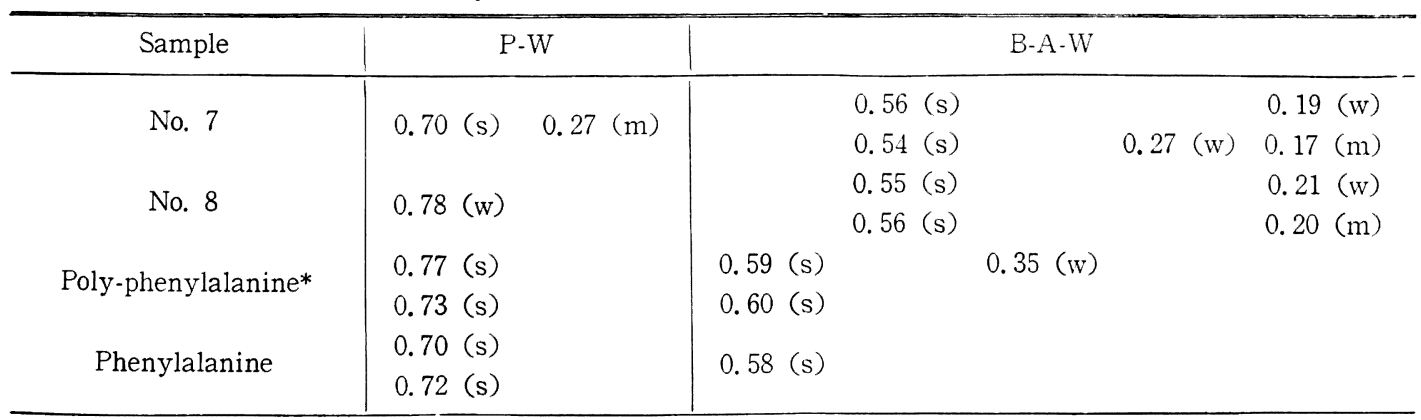

* Obtained by the $n$-hexylamine-initiated polymerization of phenylalanine NCA. 
Table 6. Polymerization of $\beta$-chloracrylamide.

$[\mathrm{M}]_{0}: 0.97 \mathrm{~mol} / l(1 \mathrm{~g} / 10 \mathrm{ml})$

Polymerization time $24 \mathrm{hr}$

\begin{tabular}{|c|c|c|c|c|c|c|c|}
\hline \multirow[b]{2}{*}{ No. } & \multicolumn{2}{|c|}{ Catalyst } & \multirow[b]{2}{*}{ Solvent } & \multirow{2}{*}{$\begin{array}{l}\text { Tempera- } \\
\text { ture } \\
\qquad\left({ }^{\circ} \mathrm{C}\right)\end{array}$} & \multicolumn{3}{|c|}{ Product* } \\
\hline & Kind & $\begin{array}{c}\text { Concentration } \\
(\mathrm{m} \mathrm{mol} / \mathrm{l})\end{array}$ & & & $\begin{array}{c}\text { Weight } \\
(\mathrm{g})\end{array}$ & $\begin{array}{l}\text { Yield } \\
(\%)\end{array}$ & $\eta_{s p} / C$ \\
\hline 9 & $t-\mathrm{C}_{4} \mathrm{H}_{9} \mathrm{ONa}$ & 104 & DMF & 90 & 0.063 & 6.3 & \\
\hline 10 & $n-\mathrm{C}_{4} \mathrm{H}_{9} \mathrm{Li}$ & 80 & DMF & 90 & 0.367 & 36.7 & $0.103(C=1.07 \mathrm{~g} / \mathrm{d} l)$ \\
\hline 11 & $n-\mathrm{C}_{4} \mathrm{H}_{9} \mathrm{MgBr}$ & 10 & DMF & 90 & 0.153 & 15.3 & \\
\hline 12 & $n-\mathrm{C}_{4} \mathrm{H}_{9} \mathrm{MgBr}$ & 100 & $\mathrm{DMF}$ & 90 & 0.996 & 99.6 & $0.076(C=1.13 \mathrm{~g} / \mathrm{d} l)$ \\
\hline 13 & $n-\mathrm{C}_{4} \mathrm{H}_{3} \mathrm{MgBr}$ & 100 & $\mathrm{DMF}$ & 50 & 0.255 & 25.5 & $0.109(C=0.96 \mathrm{~g} / \mathrm{d} l)$ \\
\hline 14 & $n-\mathrm{C}_{4} \mathrm{H}_{9} \mathrm{Li}$ & 80 & DMSO & 90 & 0.227 & 22.7 & $0.115(C=1.17 \mathrm{~g} / \mathrm{d} l)$ \\
\hline 15 & $n-\mathrm{C}_{4} \mathrm{H}_{9} \mathrm{Li}$ & 80 & $\mathrm{CB}$ & 90 & 0.109 & 10.8 & \\
\hline
\end{tabular}

* Ether insoluble part

体の水素䔟動重合によって $\alpha$-ペプチド結合を持つポリ ペプチドを合成するには，非常に強い電子吸引性の置換 基（たとえばニトロ基）を導入することが必要であると いえる。

\section{$3.3 \beta$-クロルアクリルアミドの重合}

フクリルアミドの $\beta$-水素を電子吸引性基 Cl で置換し

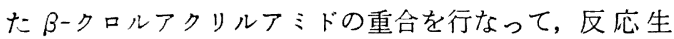
成物の㩐造について検討した。まず重合条件と反応生成 物の収量之の関係について調べた結果を Table 6 に示 した。共験 9〜12は触媒の種類の影䈏を調べたものであ る。使用した 3 種の触媒のうち $n-\mathrm{C}_{4} \mathrm{H}_{9} \mathrm{MgBr}$ が最も好 収率で生成物を与えた。実験 12 と 13 は重合温度の影響 を調べたものである。50 $\mathrm{C} よ り 90^{\circ} \mathrm{C}$ の方が生成物の 収率は上昇した。実験 $10 ， 14 ， 15$ は溶媒の影響を調べ たものて市る，使用した 3 種の溶媒のらち，DMFが最 もよい収率を与えた。

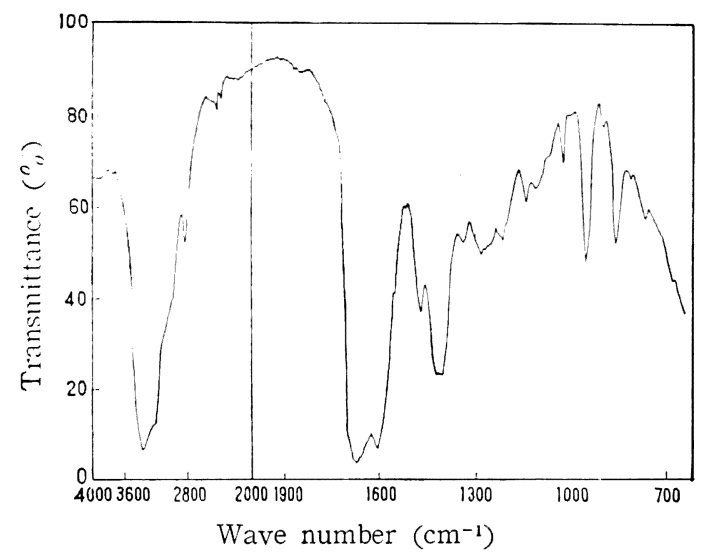

Fig. 2-a. Infrared spectrum of trans- $\beta$-chloracrylamide.
次に反応生成物の性筫について若干の検討を加えた。 まずモノーーと代表的な反応生成物の赤外スペクトルを Fig. 2 に示した。これよりポリマーが得られたことが 推定される。すなわち，モノマー（Fig. 2-a）において 認められた $940 \mathrm{~cm}^{-1}$ の trans 2 重結合に基く吸収が反 応生成物（Fig. 2-b）においては認められない。さらに 反応生成物は 1500 $1600 \mathrm{~cm}^{-1}$ に置換アミド基に基くと 考えられる吸収を示す。ポリマーの生成は, Table 6 に 示した反応生成物の罡元粘度の值からも支持される。

次に反応生成物の加水分解を行ない，加水分解物のぺ 一パークロマトグラフィーを行なって生成物を分析し た。絬果を Table 7 に示した。これよりすべての反応 生成物の加水分解物中にアミノ酸が生成していることが わかる。したがって よってポリペプチドが生成したことが明らかである。ぺ プチド結合が $\alpha$-ペプチド結合（A）であるかどらかにつ

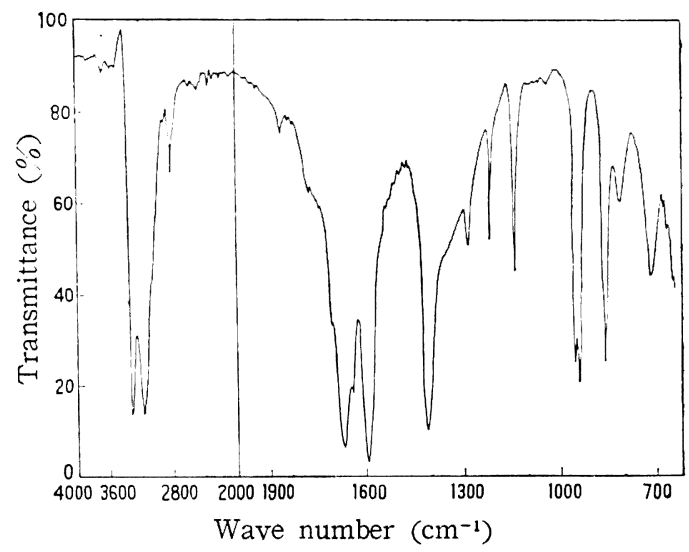

Fig. 2-b. Infrared spectrum of poly-trans- $\beta$ chloracrylamide. 
Table 7. $R_{f}$ values of the hydrolyzates of poly- $\beta$-chloracrylamide.

\begin{tabular}{|c|c|c|c|c|c|c|c|c|}
\hline Sample & \multicolumn{5}{|c|}{$\mathrm{P}-\mathrm{W}$} & \multicolumn{3}{|c|}{ B-A-W } \\
\hline No. 9 & $0.90(w)$ & & & $\begin{array}{l}0.25(\mathrm{~m}) \\
0.25(\mathrm{w})\end{array}$ & & & $0.25(\mathrm{w})$ & $0.19(\mathrm{w})$ \\
\hline No. 10 & & $\begin{array}{l}0.71(\mathrm{~s}) \\
0.73(\mathrm{w})\end{array}$ & $0.59(w)$ & $\begin{array}{l}0.25(\mathrm{~m}) \\
0.28(\mathrm{w})\end{array}$ & $0.11(w)$ & & $0.25(\mathrm{~s})$ & $0.18(\mathrm{~m})$ \\
\hline No. 11 & $0.80(w)$ & $0.75(w)$ & & $\begin{array}{l}0.30(w) \\
0.29(w)\end{array}$ & & $0.31(w)$ & $0.27(\mathrm{~s})$ & \\
\hline No. 12 & & $\begin{array}{l}0.73(\mathrm{~s}) \\
0.70(\mathrm{w})\end{array}$ & & $\begin{array}{l}0.26(\mathrm{~m}) \\
0.28(\mathrm{w})\end{array}$ & & & $0.28(\mathrm{~s})$ & $0.20(\mathrm{w})$ \\
\hline No. 13 & $0.81(\mathrm{~s})$ & & & $\begin{array}{l}0.25(\mathrm{~m}) \\
0.29(\mathrm{w})\end{array}$ & & & $0.25(\mathrm{~s})$ & $0.17(\mathrm{~m})$ \\
\hline No. 14 & $0.81(w)$ & & & $0.27(w)$ & & & $0.24(w)$ & $0.16(\mathrm{w})$ \\
\hline No. 15 & $0.92(w)$ & & & $0.27(w)$ & & & $0.26(\mathrm{w})$ & $0.17(w)$ \\
\hline
\end{tabular}

Table 8. Nitrogen analysis,of poly- $\beta$-chloracrylamide No. 10 of Table 6.

\begin{tabular}{|c|c|c|}
\hline \multicolumn{2}{|c|}{ Total nitrogen $(\%)$} & \multirow{2}{*}{$\begin{array}{c}\text { Amide nitrogen } \\
\left(\begin{array}{c}0 \\
0\end{array}\right)\end{array}$} \\
\hline Theoretical & Observed & \\
\hline 13. $27^{*}$ & $11.60 \pm 0.40^{* *}$ & $8.45 \pm 0.05^{* *}$ \\
\hline
\end{tabular}

* Value for monomer

** Mean value of the data in duplicate

いては，標準試料としての ßークロルアラニンについて のペーパークロマトグラフィーが行なわれればならな い。ßークロルアラニンの合成は可能である'依が，その実 験操作上の詳細は報告光れていない。本研究においては ßークロルアラニンについての実験が行なわれなかった ので, ポリアー中のペプチド結合の性質については結論 を下すことができない。

最後に, 反応生成物中のペプチド結台 $(A+B)$ の割合 を定量するため，窒素分析を行なった。結果をTable 8 に示す。p-ニトロ桂皮酸アミドのときのように, 全窒 素量は理論值よりも小さい。しかし，これを無視すれば, 全窒素量に対するアミド窒素量の比 0.73 から， ポリー 一中の反復単位の約 $3 / 4$ はビニル重合型の反復単位 (C) から成っていることがわかった。

\section{4. 結言}

i ） $p$-ニトロ桂皮酸アミドは塩基性触媒によって重 台し, $\eta_{s p} / C \fallingdotseq 0.09$ のポリマーとなる。ポリマーの約 $1 / 3$ はペプチド結合を有し，その中には $\alpha$-ペプチド結合が 存在する。

ii）桂皮酸了ミドは塩基性触媒によって重台し，ポ リペプチドを与えるが， $\alpha$-ペプチド結合を生じない。 $\alpha$ ーペプチド結台を生じるためには $p$-ニトロ基が必要であ
る。

iii） $\beta$-クロルアクリルアミドは塩基性触媒によって 重合し, $\eta_{s p} / C \fallingdotseq 0.1$ のポリマーを与える。ポリマーの 収率に刘する重合条件の影響は

$$
\begin{aligned}
& n-\mathrm{C}_{4} \mathrm{H}_{9} \mathrm{MgBr}>n-\mathrm{C}_{4} \mathrm{H}_{9} \mathrm{Li}>t-\mathrm{C}_{4} \mathrm{H}_{9} \mathrm{ONa} \\
& 90^{\circ} \mathrm{C}>50^{\circ} \mathrm{C} \\
& \mathrm{DMF}>\mathrm{DMSO}>\mathrm{CB}
\end{aligned}
$$

であった。ポリマーの約 $1 / 4$ はペプチド結合を有する が， $\alpha$-ペプチド結合が存在するかどらかは不明である。

付記: $p^{-}$ニトロフェニルアラニン, ポリーpトロフェニルアラニンおよびポリフェニルアラニン を合成し，ご提供いただいた当研究窒の鈴值一紿 氏,ならびに研究の指導と实験結果の討論をしてい ただた東村敏延助教授に厚くお゙礼申し上げます。

\section{文献}

1) D.S. Breslow, G.E. Hulse, A.S. Matlack: J. Am. Chem. Soc., 79, 3760 (1957)

2) C.H. Bamford, G.C. Eastmond, Y. Imanishi : Polymer, 8, 651 (1967)

3) Y. Iwakura, N. Nakabayashi, K. Sagara, Y. Ichikura: J. Polymer Sci., A-1, 5, 675 (1967)

4) G. Guastalla: Attr. Acad. Sci. Torino, 63, 128 (1928)

5) E. Fischer, H. Kuzel: Ber., 16, 33 (1883)

6) V. Wolf: Ber., 86, 735 (1953)

7) H.J. Backer, A.E. Beute: Rec. Trav. Chim., 54, 167 (1935)

8) E. Gryszkiewicz-Trochımowski, W. Schmidt, O. Gryszkiewicz-Trochimowski: Bull. Soc. Chim. France, 1948, 593

9) K. Kojima, N. Yoda, C.S. Marvel: J. Polymer 
Sci., A-1, 4, 1121 (1966)

10）平井通博，早津了一：薬学雑誌，71，765（1951）

11) N.O. Cheronis, T.S. Ma: "Organic Functional Group Analysis”, Interscience, New York, 569 (1964)

12）中山博之, 東村敏延, 岡村誠三：高化， 23，433
(1966)

13) N. Ogata: Bull. Chem. Soc. Japan, 33, 906 (1960)

14) J. Kollonistsch, A. Rosegay, G. Doldouras: J. Am. Chem. Soc., 86, 1857 (1964)

\title{
Synthesis of $\alpha$-Polypeptide by the Hydrogen Migration Polymerization of $\beta$-Substituted Acrylamide
}

\author{
by Yukio Imanishi*, Tadakatsu Andoh*, and Seizo Okamura*
}

In an attempt to synthesize $\alpha$-polypeptide by the hydrogen migration pulymerization of acrylamide derivatives which carry an electron-withdrawing substituent at a $\beta$-carbon, trans- $p$-nitrocinnamide and trans- $\beta$-chloracrylamide were prepared and polymerized with basic initiators. Trans-p-nitrocinnamide was polymerized to a polymer with an intrinsic viscosity of about 0.09 . About one third of the structural units in the polymer were linked by peptide bonds. Existence of the $\alpha$-peptide linkage was confirmed. Trans-cinnamide was found to give only a $\beta$-polypeptide. This indicates that a strongly electron withdrawing $p$-nitro group is necessary to induce $\alpha$-polypeptide formation. Trans- $\beta$-chloracrylamide was polymerized to a polymer with an intrinsic viscosity of about 0.1 . About one fourth of the structural units in the polymer were linked by peptide bonds. It is not known, however, whether the peptide linkage is $\alpha$ or $\beta$.

\footnotetext{
* Department of Polymer Chemistry, Kyoto University (Kyoto)
} 